\title{
Physico-Chemical and Microbiological Constituents of Honey Obtained from Tropical Rainforest Agro-Ecological Zone of Nigeria
}

\author{
Adenekan $\mathrm{MO}^{1 *}$, and Augustus $\mathrm{EO}^{2}$ \\ ${ }^{1}$ Department of Agriculture, Federal College of Agriculture, Ibadan P.M.B. 5029, Ibadan, Oyo State, Nigeria \\ ${ }^{2}$ Department of General Studies, Federal College of Agriculture, Ibadan P.M.B. 5029, Ibadan, Oyo State, Nigeria
}

\section{Article History}

Received: 02.12.2020

Accepted: 15.12 .2020

Published: 22.12.2020

Journal homepage:

https://www.easpublisher.com

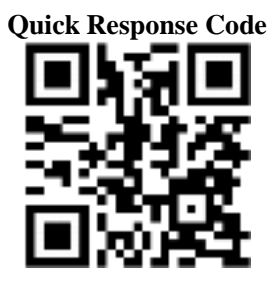

Abstract: The physico-chemical and microbiological quality of honey samples obtained from the tropical rainforest agro-ecological zone of Nigeria were investigated. There is paucity of information on the biochemical characteristics of honey produced from the rain forest zone of Nigeria; hence, the need to provide a database on the characterization of honey produced in this zone. A total of eighteen honey samples collected from this zone were analyzed for their chemical properties including moisture, ash, $\mathrm{pH}$, glucose and fructose content, while the microbial population including total plate count (TPC), total coliform and the levels of spore-forming bacteria and fungi were determined. Data obtained were analyzed statistically by Analysis of Variance (ANOVA), while sample means were separated with the aid of Least Significant Difference (LSD) at $\mathrm{P} \leq 0.05$ using Statistical Analysis System (SAS) package. The mean moisture content values ranged from

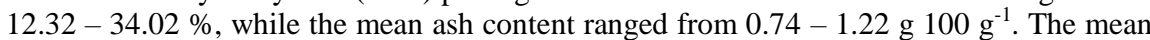
$\mathrm{pH}$ value of 2.6 obtained from honey samples collected in Akwa Ibom was significantly very low when compared with that of 4.3 and 3.2 obtained from Edo and Bayelsa States honey samples respectively. Glucose and fructose mean values detected in honey samples also showed significant values. Four mineral elements: Potassium (K), Magnesium $(\mathrm{Mg})$, Calcium $(\mathrm{Ca})$ and Iron $(\mathrm{Fe})$ were detected, but with levels varying from one place to another. Potassium $(\mathrm{K})$ was the most abundant element with a mean value of $8.06 \mathrm{ppm}$ obtained from Akwa Ibom honey samples. Results of microbiological characteristics showed that microbial profile were low for all microorganisms detected in honey samples produced from the tropical rainforest agro-ecological zone of Nigeria. Keywords: Honey, Bacterium, Spore, Fungi, Bacillus, Rainforest.

Copyright (C) 2020 The Author(s): This is an open-access article distributed under the terms of the Creative Commons Attribution 4.0 International License (CC BY-NC 4.0) which permits unrestricted use, distribution, and reproduction in any medium for non-commercial use provided the original author and source are credited.

\section{INTRODUCTION}

Honey is the natural sweet substance produced by honeybees from the nectar of blossoms or from the secretion of living parts of plants or excretion of plantsucking insects on the living parts of plants which honeybees collect, transform and combine with specific substances of their own, store and leave in the honeycomb to ripen and mature [1].

The quality of honey is mainly determined by its sensorial, chemical, physical and microbiological characteristics. Internationally, honey quality criteria are specified in regulatory standard, compiled in a Codex Alimentarius standard, which at present is under revision [2]. Honey has several sources of microbial contaminations. Primary source of which include pollen, the digestive tracts of honeybees, dust, air, soil and nectar which are somewhat difficult to eliminate. On the other hand, secondary sources due to honey handlers and processing are easier to control by the application of good manufacturing practices [3]. The major microbial contaminants of honey include moulds and yeast as well as the spores of Bacillus spp. and Clostridium spp [3], being their counts indicative of honeys' commercial quality and safety.

The present study aimed at investigating the biochemical and microbiological component of honey samples obtained from the tropical rainforest agroecological zone of Nigeria.

\section{Materials ANd Methods}

In this study, three samples of honey were randomly collected from each of the identified tropical rainforest ecological zone of Nigeria (Benin, Delta, Bayelsa, Cross River, Rivers and Akwa-Ibom States). A total of 18 samples of honey were collected in this zone and were stored in a black cupboard at room temperature until needed for analysis. The analyses were carried out in the Biochemistry and Microbiology laboratories of the International Institute for Tropical Agriculture (IITA) Ibadan in 2013. 


\section{BiOCHEMICAL ANALYSIS}

Moisture content was determined by weighing $10 \mathrm{~g}$ of honey samples in pre-weighed crucible which was then dried at $105{ }^{\circ} \mathrm{C}$ until a constant weight was obtained. Ash content was determined by igniting at $550{ }^{0} \mathrm{C}$ in a furnace to constant mass [4]. The phenolsulphuric acid method of Maynard [5] was used to determine the reducing sugar (glucose and fructose) content of the honey samples. $10 \mathrm{ml}$ of honey sample was dissolved in $250 \mathrm{ml}$ of distilled water in a calibrated flask. This was stirred thoroughly and centrifuged to get the supernatant solution for the analysis. $1 \mathrm{ml}$ of the diluted solution was pipetted into test tubes and $1 \mathrm{ml}$ of $52 \%$ phenol was added to each test tube. $5 \mathrm{ml}$ of $96 \% \mathrm{H}_{2} \mathrm{SO}_{4}$ was also added drop by drop and the test tube was allowed to stand for $10 \mathrm{~min}$ before the content was transferred into clean, greasefree bottles and read with a spectrophotometer at a wavelength of $490 \mathrm{~nm}$. A blank was prepared and used to set the equipment to the zero mark. Glucose was used as a standard. The values of the reducing sugars present in all honey samples were read from the spectrometer and recorded.

Honey samples were analyzed for crude protein using the routine Kjeldahl nitrogen method [6]. $10 \mathrm{~g}$ of homogenous honey samples was weighed into digestion flask and dissolved with $10 \mathrm{ml}$ of ultra-pure water. The diluent was transferred into the volumetric flask, while Kjedahal catalyst tablet (potassium sulphate) was added and thoroughly shaken. $20 \mathrm{ml}$ of concentrated $\mathrm{H}_{2} \mathrm{SO}_{4}$ was added and fixed into the digester. The flask was cooled and the digest transferred into $100 \mathrm{ml}$ volumetric flask. 5 drops of bromocresol (indicator) and $75 \mathrm{ml}$ of ultra-pure water were added. 10 $\mathrm{ml}$ of the digest was pipeted into the Kjeldahl distillation flask and titrated with $0.05 \mathrm{~N}$ of $\mathrm{HCl}$, while the percentage total nitrogen was calculated using the Joslyn (1970) equation:

Where $\mathrm{N}=$ normality of acid

$\%$ Total nitrogen $=\underline{14.0(\text { Sample titre }- \text { blank titre })} \quad \mathrm{X} \quad \mathrm{N}$ $10 \mathrm{x}$ wt. of sample

$\%$ crude protein $(\mathrm{CP})$ was obtained for all the honey samples using

$\% \mathrm{CP}=\%$ Total nitrogen $\mathrm{x} \quad 6.25$

The honey samples were analyzed for mineral elemental determination using Atomic Absorption Spectrophotometer (AAS) and flame photometer according to AOAC [7]. $10 \mathrm{~g}$ of honey samples was weighed and dissolved in ultra-pure water after thorough mixing. The solution was stired for $15 \mathrm{~min}$ on a mechanical stirer at $1550 \mathrm{rpm}$. A solution of Parkloric acid and nitric acid were added and mixed thoroughly. This homogenous solution was dispensed into the AAS in order to determine the concentration of $\mathrm{K}, \mathrm{Mg}, \mathrm{Ca}$ and $\mathrm{Fe}$ at different wavelengths. A standard was prepared for each of these elements.

Honey samples were analyzed using basic and additional microbiological analysis. The basic microbiological analysis consisted of total plate counts and coliform bacteria counts. The number of these microbial groups in the honey samples tested was identified and confirmed using the manual of determinative bacteriology [8]. Data generated from the laboratory analyses were analyzed statistically using Analysis of Variance (ANOVA), while the sample means were separated using Least Significant Difference (LSD) at $\mathrm{P} \leq 0.05$.

\section{RESULTS AND DISCUSSION}

The results of the biochemical characteristics of honey samples obtained from tropical rainforest agro-ecological zone of Nigeria are summarized in Table 1. Honey moisture content depends on environmental conditions and the manipulation from beekeepers at the harvest period and can vary from season to season [9]. Moisture contents of honey samples from different parts of the tropical rainforest agro-ecological zone ranged from 12.32 - $34.02 \%$. There was significant difference between the mean moisture content of $32.8 \%$ obtained from Edo State honey and $12.32 \%$ obtained from Delta State honey samples. The different moisture content of honey depends on harvest season, the degree of maturity reached in the hive and the moisture content of original plant [10].

There were no significant differences in the values of ash content of the honey samples obtained from different rainforest agro-ecological zone of

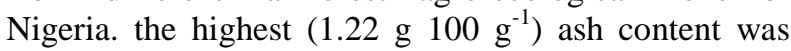
obatined from Akwa Ibom honey sample, while the

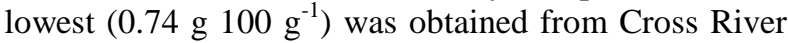
State honey sample (Table 1). Ash represents the direct measure of inorganic residues after honey carbonization. The variability in ash content may be explained by the floral source of the honey [11]. $\mathrm{pH}$ values were in the range of $4.3-2.6$. There was a significant difference in the $\mathrm{pH}$ values in honey samples obtained from Edo and Cross River states which was not significantly different $(\mathrm{P} \leq 0.05)$ when compared with the $\mathrm{pH}$ value of honey samples obtained from Rivers, Akwa-Ibom and Bayelsa states respectively. These results are in agreement with White [12] who reported that honey was characteristically quite acidic, its $\mathrm{pH}$ being between 3.2 and 4.5 . 
The mean glucose value obtained from the tropical rainforest agro-ecological zone of Nigeria showed a range of $30.14-43.12 \%$ indicating that after fructose, glucose sugar is the main constituent of honey. This result is in conformity with the research work reported by Krell [13] that the majority of sugars in honey are the simple sugars, fructose and glucose, which represent $85-95 \%$ of total sugar found in honey.

The mean values of crude protein detected in honey samples collected from different tropical rainforest agro-ecological zones of Nigeria were in trace amount with a range value of $0.022-0.052 \%$. The mean value of $0.052 \%$ obtained from honey samples collected from Cross River was significantly different from $0.022 \%$ obtained from Edo and AkwaIbom honey samples respectively (Table 1). The protein content detected is in small quantities and was in agreement with the report of Terrab et al. [14] who stated that honey is not intended as protenaceous food, but contains a series of free amino acids necessary for health promoting effects in human being.

The mineral elements detected in honey samples collected from the rainforest agro-ecological zone showed that minerals are in trace quantities. Potassium, magnesium, calcium and iron were the mineral elements detected in trace quantities, except $\mathrm{K}$ and $\mathrm{Fe}$, which were found to occur in significant quantities. $\mathrm{K}$ regulates acid-alkaline balance in the blood and is involved in the transmission of nerve impulses, activates the functions of several enzymes and the muscular function of the heart. It also has a positive effect on the function of skin and kidneys. It is the most abundant trace elements followed by $\mathrm{Fe}$ and $\mathrm{Mg}$ found in the honey samples produced in the tropical rainforest agro-ecological zone of Nigeria. This finding is in accord with Feller et al. [15] and Gonzales et al. [16] who reported that the main elements found in honey is $\mathrm{K}$ with an average of about one-third of the total composition of mineral elements in honey. Several investigators have shown that trace element contents of honey depends mainly on the botanical origin of the honey $[17,11]$, hence the different values of mineral elements obtained from honeys form rainforest zone of Nigeria.

The microbiological characteristics of honey samples obtained from the rainforest agro-ecological zone of Nigeria are summarized in Table 3. The mean total bacteria count obtained from honey samples collected from Edo State was $1.3 \times 10^{3} \mathrm{cfu} \mathrm{g}^{-1}$, while the mean value of $4.8 \times 10^{3} \mathrm{cfu} \mathrm{g}^{-1}$ was obtained from honey samples collected from Akwa-Ibom State. The lowest $\left(0.72 \mathrm{cfu} \mathrm{g}^{-1}\right)$ of TBC was obtained from Rivers
State honey sample. The results of the microbial counts in the different samples of honey obtained, showed that rainforest honeys have low levels of microbes. This is in agreement with Malika et al. [18] who reported that honey collected from Morocco contained low level of microbial cells.

Total coliform count (TCC) was not detected in honey samples obtained from Edo and Delta states, while TCC was very low and ranged from $0.5-2.0 \mathrm{x}$ $10^{3} \mathrm{cfu}^{-1}$ in honey samples collected from AkwaIbom, Cross River and Rivers states, respectively (Table 3). There were no fungal spore observed in most honey samples investigated, but a very low count ranging from $0.4-0.3 \times 10^{2} \mathrm{cfu} \mathrm{g}^{-1}$ was obtained from honey samples collected from Delta and Bayelsa states respectively (Table 3 ).

The Bacillus spp. bacterium detected in honey samples in this study was also low with $0.1 \times 10^{3} \mathrm{cfu} \mathrm{g}^{-1}$ in Delta and Akwa-Ibom states. There were no Baccilus cells in honey samples obtained from Edo, Bayelsa, Rivers and Cross River states. This is not surprising since Malika et al. [18] reported counts of less than 10 $\mathrm{cfu} \mathrm{g}^{-1}$ in Moroccan honey. The results of the selective media confirmed that the bacteria isolated from the honey samples belong to the species Pseudomonas syringae and Xanthomonas axonopode, while the Bacillus spp found were Bacillus subtilis and $B$. Mycoides. Coliform bacteria spores were not detected in most of the honey samples, except those obtained from Bayelsa and Akwa-Ibom states (Table 4).

The low levels of microbes obtained for tropical rainforest agro-ecological zone honey samples are indications that honey has high anti-microbial activity. However, microbial contamination during and / or post processing rather than the indigenous microflora of honey itself can result in spoilage or persistence of some bacteria [17]. In this investigation, the low level of total coliform count (TCC) could be explained by the evidence that honey is well preserved against bacteria so that these microorganisms would not survive unfavourable conditions. The detected microbes are plant pathogens, except Baccilus spp which is the main spoilage organism in food due to its versatile metabolism and heat resistant spores; hence, might have originated from the plant host containing the nectars where the bees visited.

The absence and low level of fungal spores and coliform bacteria means that the sanitary conditions of honeys produced in the rainforest agro-ecological zone of Nigeria were quite efficiently handled in the apiaries and post-harvesting processes are also very efficient. 
Table-1: Biochemical characteristics of honey samples obtained from Topical rainforest agro-ecological zone of

\begin{tabular}{|l|l|l|l|l|l|l|}
\hline *Source & \multicolumn{1}{|c|}{$\begin{array}{c}\text { Moisture } \\
(\boldsymbol{\%})\end{array}$} & $\begin{array}{c}\text { Ash } \\
\left(\mathbf{g ~} \mathbf{1 0 0} \mathbf{g}^{-\mathbf{1}}\right)\end{array}$ & \multicolumn{1}{|c|}{$\mathbf{\text { GH }}$} & $\begin{array}{c}\text { Glucose } \\
(\boldsymbol{\%})\end{array}$ & $\begin{array}{c}\text { Fructose } \\
(\boldsymbol{\%})\end{array}$ & $\begin{array}{c}\text { Crude protein } \\
(\boldsymbol{\%})\end{array}$ \\
\hline Edo (Benin) & $32.81 \pm 0.02$ & $0.89 \pm 0.15$ & $4.3 \pm 0.84$ & $43.12 \pm 0.15$ & $28.16 \pm 4.21$ & $0.022 \pm 0.01$ \\
Delta (Warri) & $12.32 \pm 11.34$ & $0.86 \pm 0.18$ & $3.9 \pm 0.64$ & $43.01 \pm 15.79$ & $39.11 \pm 4.32$ & $0.032 \pm 0.01$ \\
Bayelsa (Yenagoa) & $29.77 \pm 4.32$ & $0.81 \pm 0.31$ & $3.2 \pm 0.41$ & $39.22 \pm 3.49$ & $30.41 \pm 2.36$ & $0.029 \pm 0.01$ \\
Rivers (Port-Harcourt) & $33.69 \pm 5.23$ & $0.89 \pm 0.13$ & $3.1 \pm 0.04$ & $30.14 \pm 6.21$ & $19.31 \pm 4.01$ & $0.028 \pm 0.00$ \\
Cross River (Calabar) & $34.02 \pm 8.03$ & $0.74 \pm 0.17$ & $2.6 \pm 0.41$ & $36.90 \pm 3.21$ & $25.11 \pm 6.20$ & $0.052 \pm 0.02$ \\
Akwa-Ibom (Uyo) & $28.81 \pm 4.31$ & $1.22 \pm 0.31$ & $2.9 \pm 1.02$ & $41.16 \pm 9.12$ & $26.11 \pm 17.14$ & $0.022 \pm 0.00$ \\
LSD $_{0.05}$ & 6.53 & 0.25 & 1.39 & 8.35 & 11.12 & 0.02 \\
\hline
\end{tabular}

Words in parenthesis are collection points. \pm Standard deviation

Table-2: Mean mineral constituents of honey samples obtained from Tropical rainforest agro-ecological zone of Nigeria

\begin{tabular}{|l|l|l|l|l|}
\hline Source & \multicolumn{1}{|c|}{$\begin{array}{c}\text { K } \\
(\mathbf{p p m})\end{array}$} & $\begin{array}{c}\mathbf{M g} \\
(\mathbf{p p m})\end{array}$ & $\begin{array}{c}\mathbf{C a} \\
(\mathbf{p p m})\end{array}$ & $\begin{array}{c}\text { Fe } \\
(\mathbf{p p m})\end{array}$ \\
\hline Edo (Benin) & $4.78 \pm 1.02$ & $1.74 \pm 0.01$ & $0.46 \pm 0.12$ & $5.49 \pm 1.22$ \\
Delta (Warri) & $5.61 \pm 1.13$ & $1.98 \pm 0.02$ & $0.48 \pm 0.12$ & $7.16 \pm 0.12$ \\
Bayelsa (Yenagoa) & $0.02 \pm 0.00$ & $1.21 \pm 0.01$ & $0.43 \pm 0.14$ & $5.39 \pm 1.11$ \\
Rivers (Port-Harcourt) & $0.43 \pm 0.02$ & $1.03 \pm 0.01$ & $0.48 \pm 0.12$ & $2.49 \pm 0.14$ \\
Cross River (Calabar) & $5.16 \pm 1.02$ & $0.97 \pm 0.11$ & $0.48 \pm 0.16$ & $6.95 \pm 1.10$ \\
Akwa-Ibom (Uyo) & $8.06 \pm 1.25$ & $1.62 \pm 0.01$ & $0.51 \pm 0.12$ & $7.09 \pm 1.14$ \\
LSD $_{0.05}$ & 1.37 & 0.41 & 0.11 & 0.76 \\
\hline
\end{tabular}

Table-3: Microbial characteristics of honey samples obtained from Tropical rainforest agro-ecological zone of Nigeria

\begin{tabular}{|c|c|c|c|c|}
\hline Source & $\begin{array}{l}\text { Total bacterial count } \\
\quad\left(\times 10^{3} \mathrm{cfu}^{-1}\right)\end{array}$ & $\begin{array}{l}\text { Total coliform count } \\
\quad\left(\times 10^{3} \mathrm{cfu}^{-1}\right)\end{array}$ & $\begin{array}{l}\text { Total fungi count } \\
\left(\times 10^{3} \mathrm{cfu} \mathrm{g}^{-1}\right)\end{array}$ & $\begin{array}{c}\text { Bacillus spp. } \\
\left(\times \mathbf{1 0}^{3}\right)\end{array}$ \\
\hline Edo (Benin) & 1.3 & - & - & - \\
\hline Delta (Warri) & 2.8 & - & 0.4 & 0.1 \\
\hline Bayelsa (Yenagoa) & 1.4 & 1.5 & 0.3 & - \\
\hline Rivers (Port-Harcourt) & 0.72 & 2.0 & - & - \\
\hline Cross River (Calabar) & 2.6 & 0.5 & - & - \\
\hline Akwa-Ibom (Uyo) & 4.8 & 0.5 & - & 0.1 \\
\hline
\end{tabular}

Table-4: Occurrence of bacteria detected in honey samples obtained from Tropical rainforest agro-ecological zone of Nigeria

\begin{tabular}{|l|c|c|c|c|}
\hline Source & Pseudomonas spp. & $\begin{array}{c}\text { Xanthomonas } \\
\text { spp. }\end{array}$ & Bacillus spp. & Coliform bacteria \\
\hline Edo (Benin) & ++ & ++ & -- & -- \\
Delta (Warri) & ++ & -- & -- & -- \\
Bayelsa (Yenagoa) & ++ & ++ & ++ & ++ \\
Rivers (Port-Harcourt) & ++ & ++ & ++ & -- \\
Cross River (Calabar) & ++ & -- & +- \\
Akwa-Ibom (Uyo) & ++ & ++ & ++ & ++ \\
\hline
\end{tabular}

\section{REFERENCES}

1. Codex Alimentarius Commission. (2001). Codex standard for sugar (honey) supplement 2 to Codex Alimetarius Vol. 111 Food and Agricultural Organization, United Nations and World Health Organization, Rome, 137.

2. Bogdanov, S. (2004). Physicochemical methods for the characterization of unifloral honey: A review. Apidologie 35 (1): 4 - 17.
3. Snowdon, J. A., \& Cliver, D. O. (1996). Microorganisms in honey. International Journal of Food Microbiology 31 (1 - 3): 1 - 26.

4. Cavia, M. M., Fernáez-Muiño, M. A., Huidobro, J. F., \& Sancho, M. T. (2004). Correlation between moisture and water activity of honeys harvested in different years. Journal of Food Science, 69(5), C368-C370.

5. Maynard, A. J. (1970). Methods in food analysis $2^{\text {nd }}$ edition. Academic Press New York, 112-136. 
6. Joslyn, M. A. (1970). Analítico: Methods in food analysis. Physical, chemical, and instrumental methods of analysis.

7. AOAC. (2005). Official methods of analysis of the Association of Analytical Chemists $18^{\text {th }}$ edition, Arlington, Virginia. United States of America, 76.

8. Beckatt, A. H., \& Stelanke, J. D. (1986). Microbial contamination in practocal pharmaceutical chemistry $3^{\text {rd }}$ edition William Heineman Medical Book Ltd., London, United Kingdom, $4-7$.

9. Acquarone, C. Buera, P., \& Elizalde, B. (2007). Pattern of $\mathrm{pH}$ and electrical conductivity upon honey dilution as a complementary tool for discriminating geographical origin of honeys. Food Chemistry, 101: 695 - 703.

10. Finola, M. G., Lasagnov, M. C., \& Marioli, J. M. (2007). Microbiological and chemical characterization of honey from Central Argentina. Food Chemistry 100L 1649 - 1653.

11. Adenekan, M. O., Amusa, N. A., Lawal, O. A., \& Okpeze, V. E. (2010). Physicochemical and microbiological properties of honey samples obtained from Ibadan. Journal of Microbiology and Antimicrobials, 2(8): 100-104.

12. White, J.W. (1995). Physical characterization of honey: A comprehensive survey. (ed.) Crane, E. Heineman, London, United Kingdom, 239.
13. Krell, R. (1996). Value added products from beekeeping. Food and Agricultural Organization Service Bulletin 124, United Nations, Rome. Italy.

14. Terrab, A., Diez, F. Maria, J., \& Heredia, F. J. (2003). Palynological, physiochemical and colour characterization of Morrocan honeys II. Orange (Citrus spp.) honeys. International Journal of Food Science and Technology 38: 387 - 394.

15. Feller-Demalsy, M. J., Vincent, B., \& Beaulieu, F. (1989). Mineral contents and geographical origin of Canadian honeys. Apidologie, 20(1): 77 - 91.

16. Gonzalez-Miret, M. L., Terrab, A., Hernanz, D., Fernandez- Recamaleb, M. A., \& Heredia, F. J. (2005). Multivariants correlation between colour and mineral composition of honey and their botanical origin. Journal of Agriculture and Food Chemistry, 53: $2574-2580$.

17. Anon. (2001). Bees, honey: Natural products. almaleka.com/by-products/honey/h./htm retrieved March 10, 2008.

18. Malika, N., Mohammed, F., \& Chaucib, E. (2005). Microbiological and physicohemical properties of Morrocan honey. International Journal of Agriculture. Biologie, 7(5): 773 - 776. 